\title{
Land use / Land cover Mapping of Chhatarpur District, Madhya Pradesh, India Using Unsupervised Classification Technique
}

\author{
Abhishek Mishra ${ }^{1}$, Sateesh Karwariya ${ }^{2}$, Sandeep Goyal $^{3}$ \\ ${ }^{1,2}$ (Research Associate Centre for Policy Studies, associated with M.P.Council of Science and \\ Technology, Bhopal (MP) 462003) \\ 3(Sr.Scientist, Madhya Pradesh Council of Science and Technology, Bhopal (MP) 462003)
}

\begin{abstract}
Chhatarpur district located on the central portion on the plateau of Bundelkhand in M.P, the district is spread over an area of $8685.08 \mathrm{~km}^{2}$ and is located at the northern boundary of the state, laying between north latitudes $24^{\circ} 06^{\prime}$ and $25^{\circ} 20^{\prime}$ and east longitude $78^{\circ} 59^{\prime}$ and $80^{\circ} 26^{\prime}$ falls under the survey of India toposheets No. 54O, 54P, 63C, 63D. The district is bounded by Mohaba district U.P in the north, Panna district in the east, Tikamgarh district in the west, Sagar \& Damoh district in the south. Land use/Land cover is an important parameter for developmental planning. In the present study an attempt has been made to generate the land use/land cover map from IRS satellite image using unsupervised classification. The study is based on secondary data, and using ERDAS IMAGINE software to subset the study area. The satellite imagery has used to prepare the land use and land cover map using unsupervised classification. The land use and land cover map clearly shows that area of crop land is higher than others.

In this research paper, Remotely sensed data would be used to fill the gap in the knowledge on the state of land use/Land cover in Chhatarpur district. The goal is to undertake a detailed, spatially explicit inventory of local trends in land use and land cover changes. This data coupled with the interdisciplinary assortment of scientific methods will be used to investigate the causes and consequences of land use/land cover change across a range of spatial and temporal scales. The result of this paper would contribute to developing recommendations to enhance sustainability and foster resilience.
\end{abstract}

Keywords: Land use, Land cover, LISS-3+Pan Data, Satellite imagery, Unsupervised classification technique.

\section{Introduction}

Satellite remote sensing has become an important tool for monitoring and management of natural resources and the environment. Remotely sensed data are widely used in land use/land cover classification. Land cover relates to the discernible earth surface expressions, such as vegetation, soil, water or anthropogenic features, and thus describes the Earth's physical state in terms of the natural environment and the man-made structures (Xavier Baulies and Gerard Szejwach, 1998). Essentially, land cover can have only one class or category at a given time and location, and can be mapped using suitable remote sensing data with spectral signatures. Land use is an expression of human uses of the landscape, e.g. for residential, commercial, or agricultural purposes, and has no spectral basis for its unique identification. Thus it cannot be explicitly derived from image data, but only infrared by visual interpretation or assessed in the framework of object-based contextual analysis.

Land use is obviously constrained by environmental factors such as soil characteristics, climate, topography and vegetation. But it also reflects the importance of land as a key and finite resource for most human activities including agriculture, industry, forestry, energy production, settlement, recreation, and water catchment and storage. Land is a fundamental factor of production, and through much of the course of human history, it has been tightly coupled with economic growth. Often improper Land use is causing various forms of environmental degradation, for sustainable utilization of the land ecosystems, it is essential to know the natural characteristics, extent and location, its quality, productivity, suitability and limitations of various land uses. Land use is a product of interactions between a society's cultural background, state, and its physical needs on the one hand, and the natural potential of land on the other (Balak Ram and Kolarkar 1993). In order to improve the economic condition of the area without further deteriorating the bio environment, every bit of the available land has to be used in the most rational way. 


\section{Study Area}

The Chhatarpur district is situated at north east border of Madhya Pradesh. This District is spread over an area of $8685.08 \mathrm{~km}^{2}$. With longitudes and latitudes of $24^{\circ} 06^{\prime} \& 25^{\circ} 20^{\prime}$ on North $78^{0} 59^{\prime} \& 80^{\circ} 26^{\prime}$ on East respectively. The District is touched by Mohoba District (Uttar Pradesh) in the East, Tikamgarh (M.P.) in West and Sagar (M.P.) in South.The District Chhatarpur were known after the name of the great warrior of the region Maharaja Chhatrasa. This District was previously under the Vindhya Pradesh. However at the time of formation of the Madhya Pradesh, it was included in Madhya Pradesh on $1^{\text {st }}$ November 1956.

As per the 2011 census, the total population of the district was 17, 62, 857. There are 9, 35,870 males and 8, 26,951 females in the District. Total Literates in the District are 9, 62,827 out of which 5, 85,128 are males and 3, 77,694 are females.

The disparity in the economy seen at various levels. Basically the district has an agrarian economy with operational holding of 2.89 hectare, out of which 1, 07682 are under irrigation. Level of industrialization is not encouraging. The majority of the population of the district migrates to big cities in search of employment and their livelihood. Education is not merely a means of better income and employment opportunities for individuals for higher economic growth potential. Thus a social benefit of education is spread in many directions.

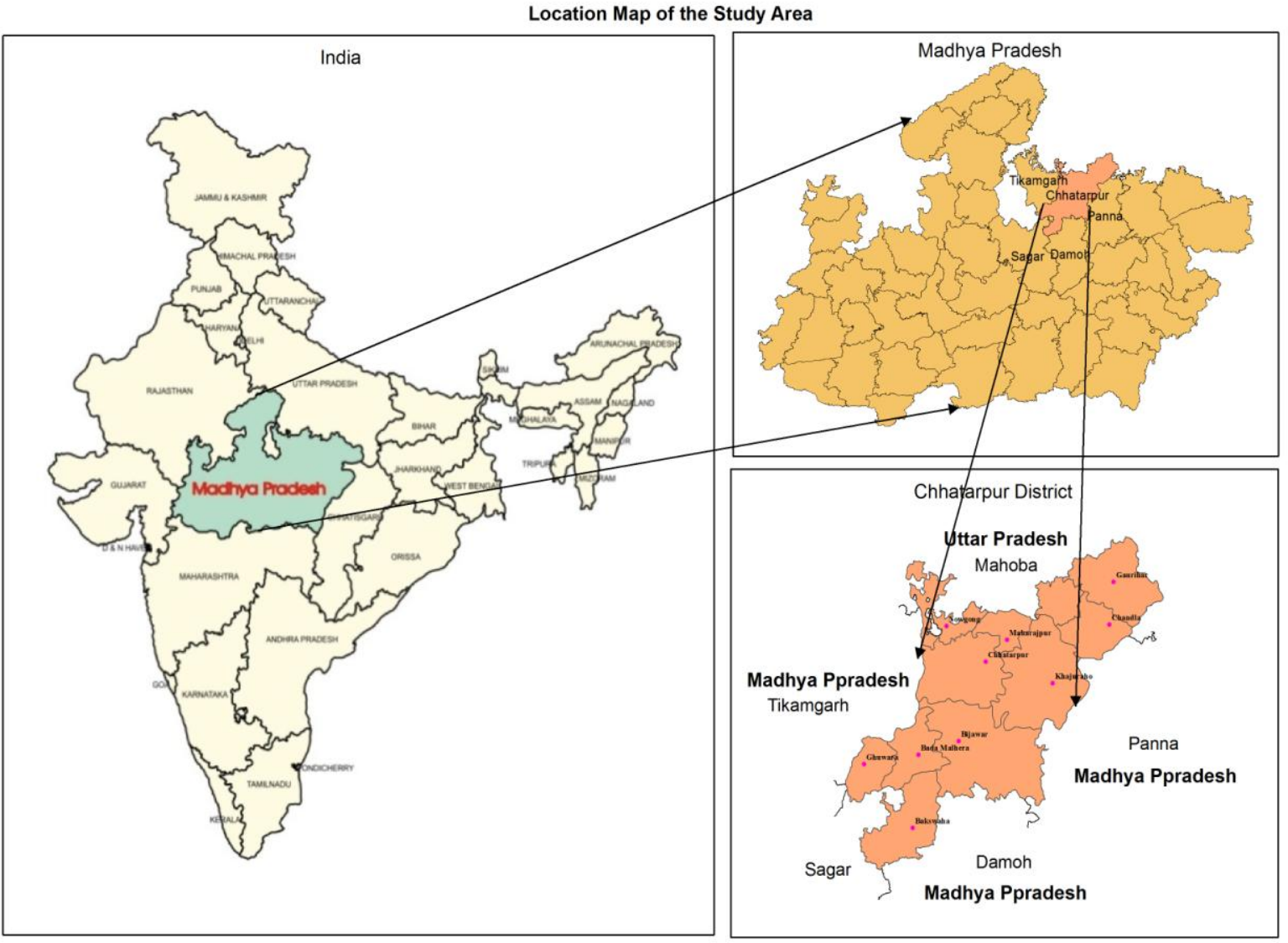

Figure 1: Location Map of the Study Area

Khajuraho, the famous tourist attraction in India, is situated in the district of Chhatarpur. Khajuraho has a range of temples with remarkable work of stone carving on the walls. They were created by the Chandela kings who ruled Bundelkhand, before the rise of Bundela in the region.

Paddy, Jowar, Maize, Tuar, Urad, Til, groundnut, Soyabean, Sugarcane (Kharif) and wheat, Gram, Alsi, Muster, Rai \& Vegetable (Rabi) are the main crops. The total irrigated area is $2265.81 \mathrm{sq} . \mathrm{km}$ of which $204.66 \mathrm{sq} \mathrm{km}$ irrigated by canals, 16.99 sq. $\mathrm{km}$ by tube wells and 1707.87 sq. $\mathrm{km}$ by open wells.

Data Used:

1. SOI Toposheet

2. Satellite Data 


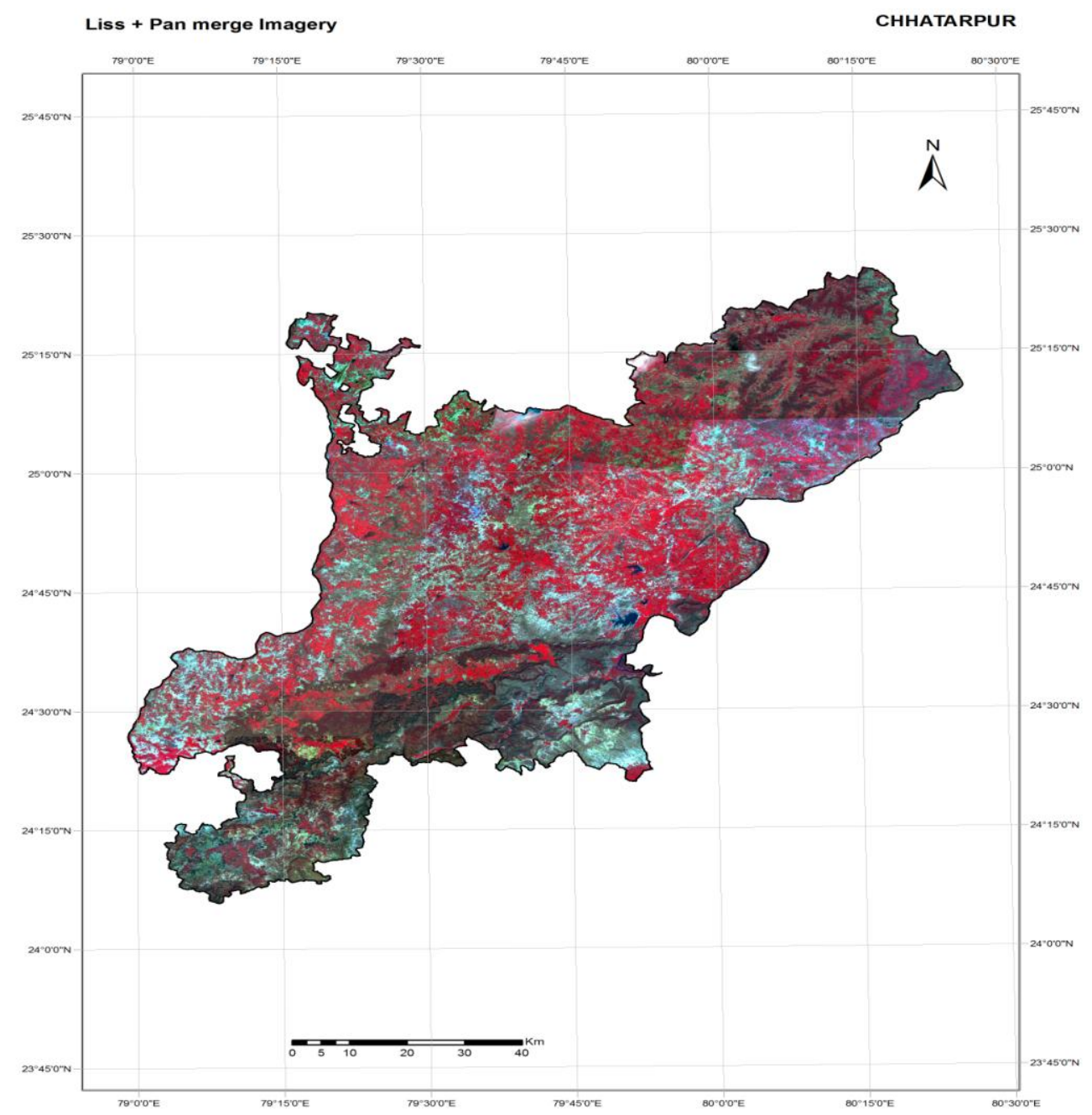

Figure 2: IRS-1C PAN + LISS-III satellite image of the study area

Image fusion techniques are useful to integrate the geometric detail of a high-resolution panchromatic (PAN) image and the spectral information of a low-resolution multispectral (MSS) image, particularly important for understanding land use dynamics at larger scale (1:25000 or lower), which is required by the decision makers to adopt holistic approaches for regional planning. Fused images can extract features from source images and provide more information than one scene of MSS image. High spectral resolution aids in identification of objects more distinctly while high spatial resolution allows locating the objects more clearly.

\section{Aim and Objective}

- Preparation of various thematic data such land use and Land cover using LISS-3+Pan Data.

- Create a land use/ land cover map from satellite imagery using unsupervised classification.

\subsection{Methodology}

- Geometric corrections of IRS-1C LISS-III+PAN data using survey of India (SOI) Toposheet at 1:50,000 scales.

- Selection of study area

- Land use/Land cover classification using unsupervised classification

- Land use /Land cover classification by normalized difference vegetation

- The extraction of thematic layers.

- Comparison of overall accuracies of each method with respect to performance Evaluation /Accuracy assessment.

- Output generation 


\subsection{Data Procession}

Analysis and interpretation of satellite data will be done by digital image processing as depicted. The process generally includes 3 steps:

1. IMAGE PRE-PROCESSING

2. IMAGE ENHANCEMENT

3. IMAGE CLASSIFICATION

The process is divided in two main processes, unsupervised classification and knowledge generation. Unsupervised classification is used to make easier classification process. Knowledge generation from the digital image, which is represented in IF-THEN model, is purposed for interpretation the image. Our research shows that SOM neural network has a simple process but high performance in land use mapping process. Several images have already been identified and acquired to represent the land use/Land cover status in the 1980's, 1990's and 2000's. One major concern over the use of satellite images during rainy season is the existence of cloud cover. Such a condition may limit the amount of information that may be extracted from these images, and would create information gaps and loss of valuable data (Al-Tahir et al 2008). To overcome these problem use temporal data.

\subsection{Field surveys}

Field surveys will be conducted within the study areas to determine the major types of land use and land cover. Such data would be used in two aspects of the mapping of land use land cover. Firstly it will aid in land use and land cover classification, by associating the ground features of a specific type of land use and land cover with the relevant imaging and spectral characteristics. Secondly, ground data will be used for accuracy assessment of the developed land use and land cover maps.

\section{Result}

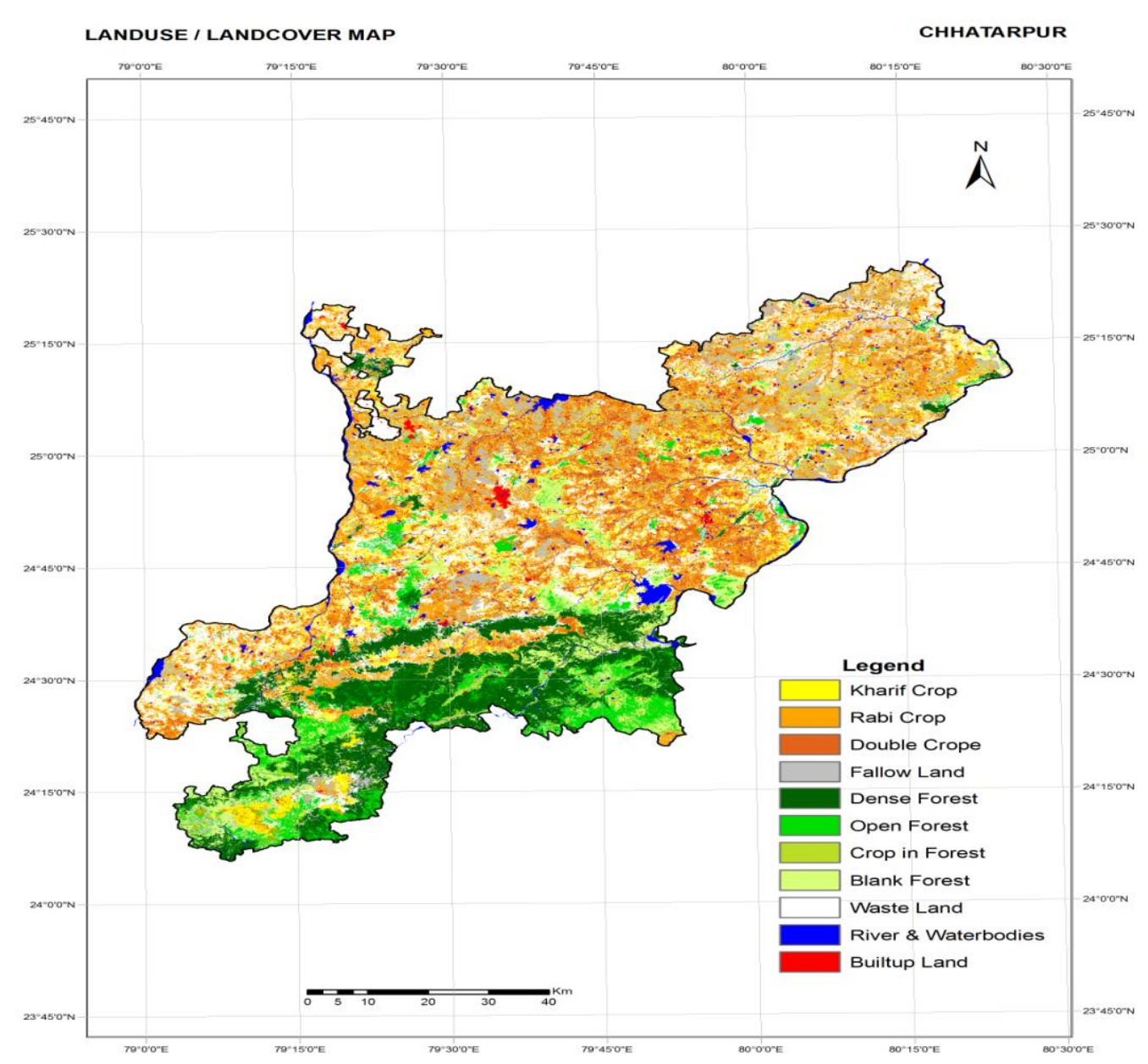

Figure3: Land use and Land cover details of the study area 


\begin{tabular}{|l|c|c|}
\hline Land Use/Land Cover & Area in ha & Area in \% \\
\hline Kharif Crop & 98273.25 & 11.32 \\
\hline Rabi Crop & 170932.61 & 19.68 \\
\hline Double Crop & 102315.06 & 11.78 \\
\hline Fallow Land & 53316.67 & 6.14 \\
\hline Dense Forest & 116774.12 & 13.45 \\
\hline Open Forest & 60301.96 & 6.94 \\
\hline Crop in Forest & 7110.07 & 0.82 \\
\hline Blank Forest & 44930.91 & 5.17 \\
\hline Waste Land & 174963.58 & 20.15 \\
\hline River \& Waterbodies & 28602.09 & 3.29 \\
\hline Builtup Land & 10987.75 & 1.27 \\
\hline Total & $\mathbf{8 6 8 5 0 8 . 0 5}$ & $\mathbf{1 0 0}$ \\
\hline
\end{tabular}

Table: Area of the different categories of land use and land cover

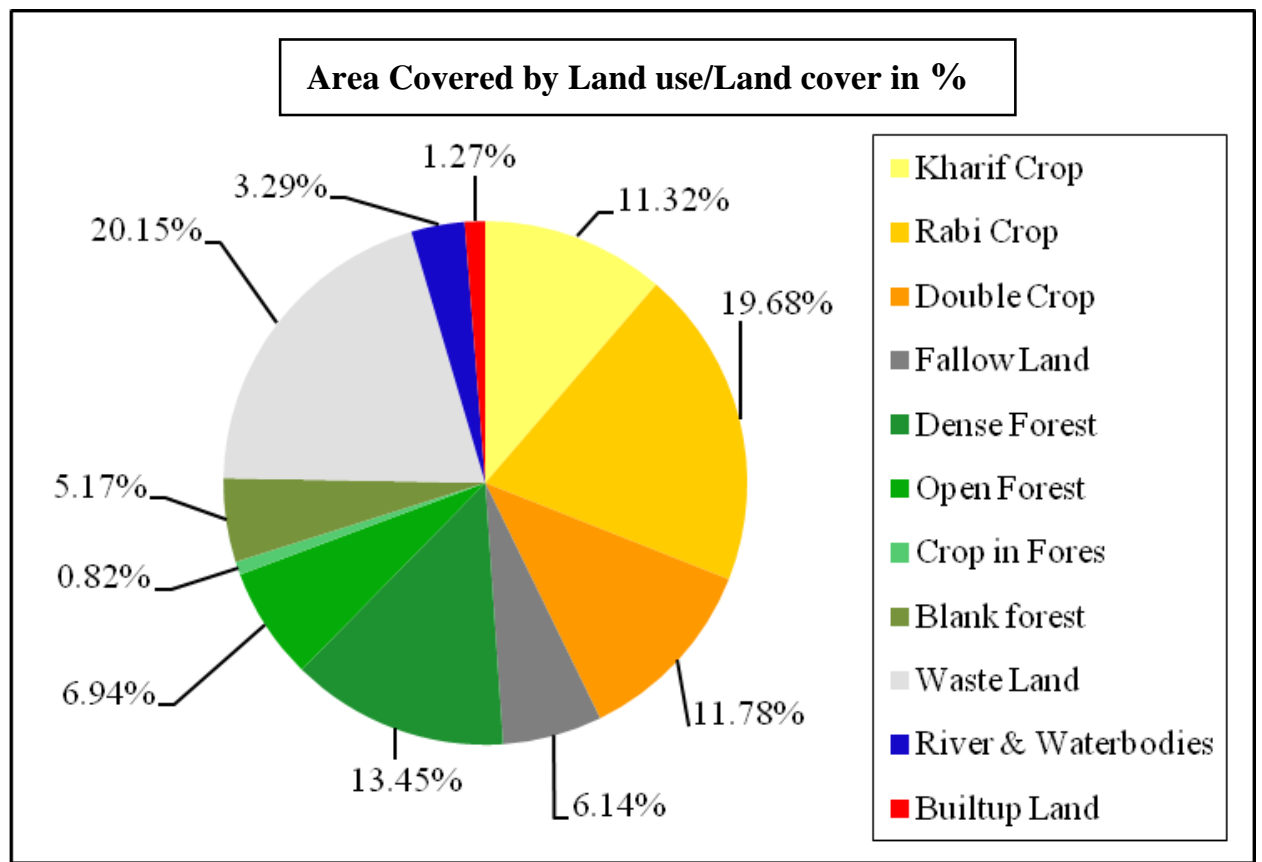

Figure 5: Showing land use and land cover area as a percentage

The land use and land cover map clearly shows that area of cropland is higher than others. Open Land/Waste land has 174963.58 hectare area it occupies second place in this district, dense forest getting third place has 116774.12 hectare area.

The classification accuracies were interpreted in terms of
(a) Effect of spatial resolution with same bandwidth.
(b) Comparison of three band set with MIR as either an additional band or a replacement,
(c) Effect of date of acquisition

\subsection{Accuracy Assessment:}

The classification accuracy is most important aspect to assess the reliability of maps, especially when comparing different classification techniques. During this study the accuracy assessment method were used. Accuracy assessment, automatic random point to be selected by software. This method shows above 90-94\% accuracy of map. 


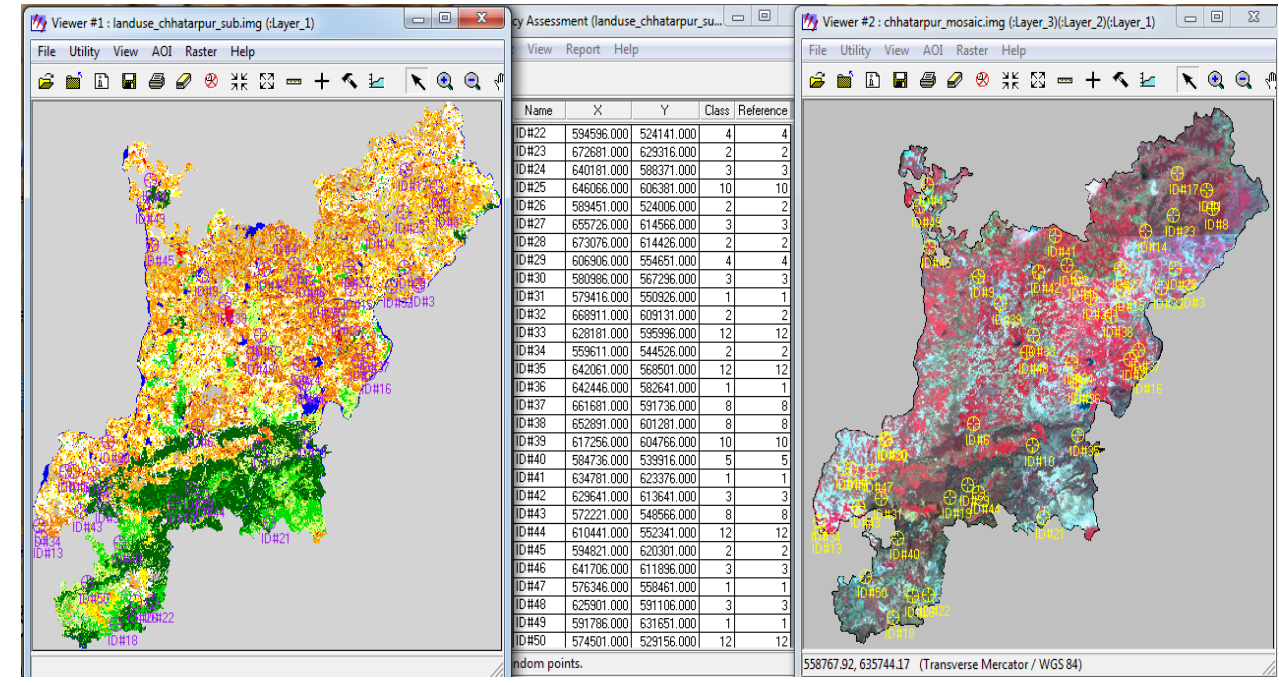

Figure 6: Images showing the accuracy assessment

\section{Conclusion}

Present study shows that how to classify land use and land cover from satellite imagery, we have calculated land use/land cover area using unsupervised classification, the land use/ land cover map clearly shows that area of cropland is higher than others. The superior performance of neural network in terms of good classification accuracy has been reported earlier (Paola J.D. and Schowengrdt R.A). The present study also supports their results by achieving highest accuracy even in case of Land use land cover mapping.

Journal Papers:

\section{References}

[1] Anderson, et al. 1976. A Land Use and Land Cover Classification System for Usewith Remote Sensor Data. Geological Survey Professional Paper No. 964, U.S.Government Printing Office, Washington, D.C. p. 28.

[2] Bisht, B.S. and Kothyari, B.P. (2001). LandCover Change Analysis of Garur Ganga Watershed Using GIS/Remote Sensing Technique. , Indian Soc.Remote Sensing, 29(3):165-174.

[3] Jayakumar, R. and Ramasamy, SM. (1996). Groundwater Targeting in Hard rock Terrain Through Geomorphic Mapping: A case study in part of South India. Asian Pacific Remote Sensing and GIS Journal, Vol.8, No.2, I. pp.1723.

[4] Karwariya Sateesh, Goyal Sandip (2011). Land use and Land Cover mapping using digital classification technique in Tikamgarh district, Madhya Pradesh, India using Remote Sensing. INTERNATIONAL JOURNAL OF GEOMATICS AND GEOSCIENCES Volume 2, No 2, 2011.

[5] S.Sudhakar et, al. (1999). Techniques of Classification for Land use/Land cover with special reference for Forest type mapping in Jaldapara Wild life Sanctuary. Journal of the Indian society of Remote Sensing, Vol. 27.No.4, 1999.

[6] Sateesh Karwariya, Shashikant Tripathi (2012) Landuse/Landcover Mapping of Achanakmar Amarkantak Biosphere Reserve, India Using Unsupervised Classification Technique. International Journal Of Computational Engineering Research (ijceronline.com) Vol. 2 Issue. 5

[7] Singh, A. 1989. Digital Change Detection Techniques Using Remotely Sensed Data. International Journal of Remote Sensing. Vol. 10, No. 6, p. 989-1003.

\section{Chapters in Books:}

[8] Adeniyi P.O and Omojola A. (1999) Landuse landcover change evaluation in Sokoto - Rima Basin of North Western Nigeria based on Archival of the Environment (AARSE) on Geoinformation Technology Applications for Resource and Environmental Management in Africa. Pp 143-172.

[9] SukhatmeP.V. and Panse V.G. (1951). Crop surveys in India - II Jr. of Indian Society of Agricultural Statistics. Pp 97-168.

\section{Proceedings Papers:}

[10] Arvik, J.H. 1997. A review of remote imaging source provider. Modern Agriculture, journal for site-specific crop management.

[11] Ram Chandra, T.V. S Uttam Kumar (2005): from Abstract of their paper presented at map India; geomedia 2005, Books: Image fusion in GRDSS for land use mapping.

[12] Jenson, J.R., 1986 "Digital image processing.

[13] Jenson, J.R, 2002"Digital image processing.

[14] Lillesand, J.M. and Kiefer, R.W., "Remote sensing and image interpretation 